УДК $796.011 .3(075.8)$

DOI: https://doi.org/10.33989/2524-2474.2019.73.180886

\title{
МАКСИМ ПРИЛУЦЬКИЙ
}

ORCID:https://orcid.org/0000-0003-1368-060X

(Полтава)

Place of work: Poltava V.G. Korolenko National Pedagogical University

Country: Ukraine

Email: Priluky1402@gmail.com

\section{СУЧАСНІ ТЕХНОЛОГІЇ ОЗДОРОВЧО-РЕКРЕАЦІЙНОЇ РУХОВОЇ АКТИВНОСТІ}

В статті доведено необхідність підготовки висококваліфікованих фахівців нової генерації, здатних ефективно керувати соціально-культурною сферою, колективом (зокрема, спортивним), реформувати оздоровчорекреаційну сферу з метою найповнішого задоволення потреб усіх верств населення. Майбутній фахівець фізичної культури, учитель фізичного виховання, тренер 3 виду спорту $\epsilon$ носієм і творцем технологій оздоровчо-рекреаційної рухової активності як соціального феномену. Аргументовано, що фізкультурно-оздоровчі та рекреаційні проекти спрямовані на зміцнення внутрішніх ресурсів студентської молоді, сприяють фізичному оздоровленню особистості, розвитку активного відпочинку, популяризації здорового способу життя. Управління спортивно-оздоровчими та рекреаційними проектами передбачає володіння загальнопрофесійними (педагогічними, соціально-культурними, психологічними) та спеціальними (загальних закономірностей, що характеризують будь-які проекти) знаннями.

Ключові слова: педагогічна технологія; оздоровчо-рекреаційна рухова активність; рекреаційні проекти; спортивно-оздоровчі проекти.

Постановка проблеми. Сучасний стан здоров'я населення України викликає занепокоєння фахівців різноманітних сфер діяльності людини. Дефіцит рухової активності негативно впливає на організм людини. Гіпокінезія зумовлює більше 6\% смертності у світі (щорічно понад 3,2 млн. випадків), її визнано в якості четвертого за значимістю фактору ризику смертності у світі. У Європі гіпокінезія спричиняє близько 3,5\% захворюваності та до 10\% смертності. Сидячий спосіб життя негативно впливає передусім на функціонування серцево-судинної системи та підвищує ризик розвитку відповідних захворювань, що спричиняють понад $60 \%$ передчасної смертності в Україні.

У національній стратегії з оздоровчої рухової активності в Україні на період до 2025 року «Рухова активність - здоровий спосіб життя - здорова нація» говориться про те, що на початку XXI століття достатній рівень оздоровчої рухової активності (не менше 4 - 5 занять на тиждень тривалістю одного заняття не менше 30 хвилин) мали лише 3\% населення віком від 16 до 74 років, середній рівень (2 - 3 заняття на тиждень) - 6\%, низький рівень (1 - 2 заняття на тиждень) - 33\% населення (Національна стратегія, 2016).

Аналіз останніх досліджень і публікацій. Проблему здоров'язбережувальних технологій, особливості їх реалізації та застосування в системі освіти досліджено в працях Т. Бойченко, О. Ващенко, С. Гаркуші, В. Єфімової, О. Іонової, П. Хоменка та ін. Фізкультурно-оздоровчі та рекреаційні технології вивчено в працях О. Андрєєвої, О. Боднар, І.Вовченко, О. Саїнчук, 0. Корносенко, М. Чернявського. Проблема оздоровчо-рекреаційних технологій та якість життя людини була предметом дослідження Ю. Павлової (2016), специфіку проектування спортивних та рекреаційно-оздоровчих проектів розкрито в працях I. Петрової (2007), теоретико-методологічні засади рекреаційної діяльності різних груп населення - в дослідженні О. Андрєєвої (2014). 
Але не зважаючи на значні наукові та практичні напрацювання українських та зарубіжних учених, зауважимо, що проблему формування та реалізації сучасних технологій оздоровчо-рекреаційної рухової активності досліджено недостатньо.

Мета статті полягає в аналізі та узагальненні наукових досліджень з питань формування та розвитку сучасних технологій оздоровчо-рекреаційної рухової активності.

Виклад основного матеріалу. Всесвітня організація охорони здоров'я виділила так звані чинники ризику, які сприяють порушенню здоров'я. Серед них основне значення мають: високі темпи сучасного життя, нервове перенапруження, незбалансоване харчування, забруднення навколишнього середовища, шкідливі звички та ін. Серед них значної ваги набуває нестача рухової активності. Норма рухової активності - поняття умовне і достатньо індивідуальне. Це - об'єм рухів, який найбільш задовольняє потреби організму, що сприяє зміцненню здоров'я, гармонічному розвитку, доброму самопочуттю, високій працездатності і життєвій активності (Круцевич, \& Безверхня, 2010).

Стан здоров'я людини є динамічним, постійно змінюється відповідно до змін зовнішніх умов. У зв'язку з цим, здоров'я можна визначити як процес збереження та розвитку фізіологічних, біологічних і психічних функцій оптимальної трудової та соціальної активності при максимальній тривалості творчого життя. Здоровий спосіб життя розуміють як форму повсякденного життя, яка відповідає гігієнічним принципам, розвиває адаптивні можливості організму, сприяє успішному відновленню, підтримці і розвитку його резервних можливостей, повноцінному виконанню особистістю соціально-психологічних функцій.

Всесвітня організація охорони здоров’я виокремлює такі компоненти якості життя: 1) фізичне благополуччя; 2) психічне благополуччя; 3) суспільне благополуччя; 4) духовне благополуччя; 5) навколишнє середовище; 6) автономність (Имас, Дутчак, \&Трачук, 2013; Приступа та ін., 2010).

Усвідомлена рухова активність людини в залежності від цілей та умов реалізації класифікується на: рухову активність в освітній сфері; рухову активність в трудовій діяльності; рухову активність побутової спрямованості; рухову активність з лікувальною метою; рухову активність під час дозвілля (Товт, Маріонда, Сивохоп, \& Сусла, 2015). Рухова активність людини в залежності від особливостей її використання класифікується на: повсякденну рухову активність та спеціально організовану рухову активність.

У сучасних наукових розвідках термін «технології оздоровчо-рекреаційної рухової активності» трактується як самостійне соціальне явище, що полягає у регулярному використанню різними групами населення доступних видів організованої оздоровчо-рекреаційної рухової активності середньої інтенсивності та доступного об'єму навантаження під час занять у формальних та неформальних групах, або ж самостійно з метою відновлення працездатності, збереження здоров'я та покращення якості життя (Товт, Маріонда, Сивохоп, \& Сусла, 2015, с. 13).

Розрізняють такі видові ознаки технологій оздоровчо-рекреаційної рухової активності як соціального явища: доступності організованої рухової активності, яка є визначальною ознакою цього соціального явища; можливості проведення занять у вільний час від навчання або трудової діяльності, тобто під час дозвілля; проведення занять у формальних та/або неформальних групах, як правило, самостійно за визначеною інструкцією або під керівництвом тренера чи інструктора; спрямованість на відновлення працездатності, збереження здоров'я людини та покращення якості її життя (Товт, Маріонда, Сивохоп, \& Сусла, 2015).

Проведений аналіз світового та національного досвіду оздоровчо-рекреаційної діяльності дозволив виділити 4 групи програм такої діяльності: спортивні програми - спеціально організовані загальнодоступні масові спортивні заходи, що можуть проводитися як у формі змагань, так і у формі спортивних фестивалів, показових спортивних виступів; фітнес-програми - заняття фізичними вправами з направленістю на підвищення функціональних можливостей організму та профілактику різноманітних захворювань людей, що здійснюються самостійно або у формальних групах у фітнес-центрах, фітнес-клубах, школах фітнесу тощо; рекреаційні програми - заняття фізичними вправами розважального характеру, що здійснюються самостійно або у неформальних групах за місцем проживання та/або масового відпочинку людей, у спеціальних рекреаційних місцях (бази відпочинку, профілакторії, лісопаркові зони, туристичні бази тощо); оздоровчі програми - спеціальні заняття фізичними вправами лікувально-реабілітаційного напряму, що здійснюються самостійно 
або у неформальних групах за місцем проживання у спеціально призначених місцях чи у закладах масового оздоровлення людей: в профілакторіях, санаторіях, лікарнях, освітньо-виховних закладах тощо; такі заняття проводяться, як правило, у формі лікувальної фізичної культури (ЛФК).

У світовій практиці оздоровчого тренування існують різні підходи до визначення доцільного вибору фізичних вправ: вибір вправ може бути доцільним за можливості програмування їх бажаної інтенсивності; вибір вправ повинен здійснюватися за педагогічними критеріями: доступність, безпека виконання, точність дозування фізичного навантаження; вибір фізичних вправ має обумовлюватися клініко-фізіологічними критеріями, насамперед можливість ефективно впливати на активацію резервів серцево-судинної системи, підвищення аеробної продуктивності організму.

На основі аналізу комплексу літературних джерел (Андрєєва, 2014; Круцевич, \& Безверхня, 2010; Имас, Дутчак, \& Трачук, 2013) нами встановлено, що реалізація організованої оздоровчорекреаційної рухової активності дає оптимальний педагогічний в медичний ефект за умови дотримання таких принципів:

- індивідуалізації - підбір засобів і технологій оздоровчо-рекреаційної рухової активності відповідно до функціональних і фізичних можливостей кожного організму;

- систематичності - наявність науково обгрунтованого комплексу оздоровчо-рекреаційних засобів та алгоритму послідовності їхнього застосування;

- поступовості - збільшення інтенсивності та обсягів навантажень відповідно до зростання функціональних та фізичних можливостей людини;

- доступності - підбір засобів і технологій оздоровчо-рекреаційної рухової активності з урахуванням максимально всіх можливих фізичних, функціональних, культурних, психологічних, матеріальних можливостей індивіда;

- оптимізації - програмування рухової активності зі спрямуванням на досягнення належних величин фізичної працездатності.

3 позиції завдань нашого дослідження важливо врахувати результати дослідження Н. Гончарової та Г. Бутенка, які в структурі рекреаційно-оздоровчої програми пропонують виділяти три періоди: підготовчий (діагностика фізичного стану дітей; адаптація організму до фізичних навантажень), основний (підвищення рівня фізичного стану; придбання рухових умінь і навичок; розвиток фізичних якостей), підтримуючий (збереження і підтримка досягнутого рівня фізичного стану) (Гончарова, \& Бутенко, 2015).

Аналіз практики організації оздоровчо-рекреаційної активності дозволив виділити індивідуально-типологічні фактори, що стимулюють залучення людей до оздоровчо-рекреаційної рухової активності: віра людини у можливість вести активний спосіб життя; прагнення займатись оздоровчо-рекреаційною руховою активністю; отримання задоволення від рухової активності; рівень суб'єктивного сприйняття стану свого здоров'я або фізичної підготовленості; самомотивація; соціальна підтримка особам, які її потребують; очікування майбутньої користі від рухової активності; суб'єктивне відчуття користі, отриманої в результаті рухової активності.

Негативні фактори суб’єктивного характеру щодо залучення особистості до оздоровчо-рекреаційної рухової активності: низький статус здоров'я та фізичної підготовленості у загальній системі ціннісних орієнтацій людини; постійне відчуття дефіциту часу;побоювання за особисту безпеку, боязнь перетренування, травматизму; відчуття втоми і бажання пасивного відпочинку; захоплення шкідливими звичками.

Висновки та перспективи дослідження. Отже, підвищення рівня рухової активності різних верств населення $€$ ефективним напрямом вирішення проблеми здоров'язбереження. Сучасна парадигма оздоровчої рухової активності передбачає формування здоров'я особистості шляхом залучення до здорового способу життя, що сприяє покращенню якості життя людей, забезпечує гармонійний розвиток особистості. Це можливо досягнути шляхом проектування технологій оздоровчо-рекреаційної рухової активності. Саме тому перспективи подальших розвідок убачаємо в розробці та реалізації педагогічної технології управління спортивно-оздоровчими та рекреаційними проектами для студентської молоді.

\section{СПИСОК ВИКОРИСТАНОЇ ЛІТЕРАТУРИ}

Андрєєва О. В. Теоретико-методологічні засади рекреаційної діяльності різних груп населення : автореф. дис. ... д-ра наук з фіз. виховання та спорту : 24.00.02 “Фізична культура, фізичне виховання різних груп населення” / НУФВСУ. Київ, 2014а. 44 с. 
Андрєєва О. В. Фізична рекреація різних груп населення : монографія. Київ : Поліграфсервіс, 2014b. 280 c.

Гончарова Н. М., Бутенко Г. О. Обгрунтування та розроблення рекреаційно-оздоровчої технології на основі засобів оздоровчого туризму та орієнтування для дітей молодшого шкільного віку. Педагогіка, психологія та медико-біологічні проблеми фізичного виховання і спорту. 2015. № 11. C. 26-32.

Круцевич Т. Ю., Безверхня Г. В. Рекреація у фізичній культурі різних груп населення : навч. посіб. Київ : Олімп. літ., 2010. 248 с.

Національна стратегія з оздоровчої рухової активності в Україні на період до 2025 року “Рухова активність - здоровий спосіб життя - здорова нація” : Указ Президента України від 09.02.2016. URL: http://zakon.rada.gov.ua/laws/show/42/2016

Павлова Ю. Оздоровчо-рекреаційні технології та якість життя людини : монографія. Львів : ЛДУФК, 2016. 356 с.

Петрова І. В. Проектування в соціально-культурній сфері : навч. посіб. Київ : КНУКіМ, 2007. 372 с.

Стратегии и рекомендации по здоровому образу жизни и двигательной активности : сб. материалов В03 / сост.: Е. В. Имас, М. В. Дутчак, С. В. Трачук. Киев : Олимп. лит., 2013. 528 с.

Товт В. А., Маріонда І. І., Сивохоп Е. М., Сусла В. Я. Теорія і технології оздоровчо-рекреаційної рухової активності : навч. посіб. Ужгород : Говерла, 2015. 88 с.

Фізична рекреація : навч. посіб. для студ. вищ. навч. закл. фіз. вих. та спорту / Є. Н. Приступа та ін. Львів : ЛДУФК, 2010. 447 с.

Чернявський М. В. Рекреаційно-оздоровчі технології у процесі фізичного виховання молодших школярів : автореф. дис. ... канд. пед. наук: 24.00.02 / НУФВСУ. Київ, 2011. 20 с.

\section{REFERENCES}

Andrieieva, O. V. (2014a). Fizychna rekreatsiia riznykh hrup naselennia [Physical recreation of different groups of the population]. Kyiv: Polihrafservis [in Ukrainian].

Andrieieva, O. V. (2014b). Teoretyko-metodolohichni zasady rekreatsiinoi diialnosti riznykh hrup naselennia [Theoretical and methodological principles of recreational activities of different groups of the population]. (Extended adstract of PhD dissertation). National University of Ukraine on Physical Education and Sport, Kyiv [in Ukrainian].

Cherniavskyi, M. V. (2011). Rekreatsiino-ozdorovchi tekhnolohii u protsesi fizychnoho vykhovannia molodshykh shkoliariv [Theoretical and methodological principles of recreational activities of different groups of the population]. (Extended by PhD dissertation). National University of Ukraine on Physical Education and Sport, Kyiv [in Ukrainian].

Honcharova, N. M., \& Butenko, H. O. (2015). Obgruntuvannia ta rozroblennia rekreatsiino-ozdorovchoi tekhnolohii na osnovi zasobiv ozdorovchoho turyzmu ta oriientuvannia dlia ditei molodshoho shkilnoho viku [Substantiation and development of recreational and health technology on the basis of health tourism and orientation for children of junior school age]. Pedagogics Psychology Medical-Biological Problems of Physical Training Andsports, 11, 26-32 [in Ukrainian].

Imas, E. V., Dutchak, M. V., \& Trachuk, S. V. (Comps.). (2013). Strategii i rekomendatsii po zdorovomu obrazu zhizni i dvigatel'noi aktivnosti [Strategies and recommendations for a healthy lifestyle and motor activity]. Kiev: Olimp. lit. [in Russian].

Krutsevych, T. Yu., \& Bezverkhnia, H. V. (2010). Rekreatsiia u fizychnii kulturi riznykh hrup naselennia [Physical recreation of different groups of the population]. Kyiv: Olimp. lit. [in Ukrainian].

Natsionalna stratehiia z ozdorovchoi rukhovoi aktyvnosti v Ukraini na period do 2025 roku "Rukhova aktyvnist - zdorovyi sposib zhyttia - zdorova natsiia" [National Strategy for Motor Rehabilitation in Ukraine up to 2025 "Motor activity - a healthy lifestyle - a healthy nation"]. (2016). Retrieved from: http://zakon.rada.gov.ua/laws/show/42/2016 [in Ukrainian].

Pavlova, Yu. (2016). Ozdorovcho-rekreatsiini tekhnolohii ta yakist zhyttia liudyny [Recreational and recreational technologies and quality of human life]. Lviv: LDUFK [in Ukrainian].

Petrova, I. V. (2007). Proektuvannia v sotsialno-kulturnii sferi [Design in the socio-cultural sphere]. Kyiv: KNUKiM [in Ukrainian].

Prystupa, Ye. N., Zhdanova, O. M., Lynets, M. M., Martyn, P. M., Zavydivska, N. N., Chekhovska, L. Ya. ... Kukhtii, A. O. (2010). Fizychna rekreatsiia [Physical recreation]. Lviv: LDUFK [in Ukrainian]. 
Tovt, V. A., Marionda, I. I., Syvokhop, E. M., \& Susla, V. Ya. (2015). Teoriia i tekhnolohii ozdorovcho-rekreatsiinoi rukhovoi aktyvnosti [Theory and technology of recreational and recreational motor activity]. Uzhhorod: Hoverla [in Ukrainian].

\section{MAKSYM PRYLUTSKYI}

\section{MODERN TECHNOLOGIES OF HEALTH-RECREATIONAL PHYSICAL ACTIVITY}

The article deals with the features of implementation and management of modern technologies of health-recreational activity of student youth. The peculiarities of management of recreational and sport and recreational projects for student youth are studied.

The topicality of the raised problem lies in the need of highly qualified specialists'of the new generation training, who are able to manage the socio-cultural field effectively, to lead the team of people (sports teams, in particular), to reform the health-recreational and recreational field in order to meet the needs of all segments of the population fully. The professional activity of a specialists in Physical Education, teachers of Physical Education, the sports trainers of today are not limited with narrow approaches to teaching and training. The future specialist of these field is a carrier and a creator of technologies of health-recreational and recreational physical activity as a social phenomenon.

Sport and health-recreational and recreational projects are aimed at strengthening the internal resources of student youth. They contribute to the physical well-being of the individual, the development of active rest, the promotion of a healthy lifestyle.

Physical Education and health projects have the following specific features: the health status is emphasized; the diversity of living conditions and the needs of socio-demographic groups are taken into the account; the optimal combination of different sport; democratic forms of Physical culture and health activity; optional attendance of sport facilities; availability of sport centres, playgrounds and pavilions.

Thus, sport projects are aimed at the satisfying the needs of a person in the free choice of such activities, in active recreation, in the pursuit of physical improvement and strengthening of their own health, in search of a medium for communication.

The management of sport and health-recreational and recreational projects involves the possession of general knowledge (pedagogical, socio-cultural, psychological) and special knowledge (general patterns that characterize any project).

Key words: pedagogical technology, health-recreational physical activity, recreational projects, sport and recreational projects.

Одержано 05.02.2019p. 